\author{
Marija TASIĆ \\ University of Criminal Investigation and Police Studies, Serbia \\ Thomas STRAUB ${ }^{* *}$ \\ German Society of Criminalistics, Germany
}

DOI: $10.5937 /$ bezbednost2002141T

UDK: $343.143(497.11+430)$

Pregledni naučni rad

Primljen: 4. 3. 2020. godine

Datum prihvatanja: 5. 8. 2020. godine

\title{
Current legal and criminalistics possibilities in eyewitness identification procedure - a comparative analysis of German and Serbian standards ${ }^{1}$
}

Abstract: The topic of the paper is comparative scientific research analyzing the possibilities in eyewitness identification procedures in the Federal Republic of Germany and Republic of Serbia, because of the fact that identification is one of the proving actions used in both states. In this paper, what will be considered is the advantages and disadvantages of identification procedures in these states, in order to propose an optimal procedure that would be equally objective and effective both for the witnesses and the suspect.

Beside similarities in the implementation of the identification procedure in both states, there are some differences that are essentially based on normative rules, which regulate whether the police have the original authority to carry out this action or whether the authorization of a public prosecutor is required. Also, there are differences in forming the identification lineup and photo array, especially in terms of the number of people or photographs that should be presented to the eyewitness along with the suspect.

The scientific justification of this paper is reflected in the fact that eyewitness identification requires clear standards for implementation, so there is a need to create adequate preconditions

\footnotetext{
*marija.tasic@kpu.edu.rs

** thomas.straub@kriminalistik.info

${ }^{1}$ The paper is supported by the Ministry of Education, Science and Technological Development of the Republic of Serbia, under number 179045.
} 
for using this proving action in criminal proceedings, especially in cases where there is a lack of material evidence.

Keywords: identification, eyewitness, procedural provisions, criminalistics methods.

\section{Introduction}

Eyewitness identification is a very complex action subject to many limitations and discussions of its probative value. Dilemmas about the accuracy and reliability of eyewitness identification can have the implications for the legal policy and criminalistics procedures. Identification of the suspect and items related to the criminal offence play an important role in the investigation and prosecution of crimes, which is why the police are the authority that originally implements this action. Generally, identification can be defined as an operative or proving action by which the identity of a person, cadaver, crime scene or item may be determined (Bošković,1999:270). This definition implies that beside persons or items related to criminal offences, cadavers and crime scenes may also be the object of identification. Beside an eyewitness, the offender may also be a person who conducts the identification.

This paper aims to present all legal and criminalistics procedures applicable to the eyewitness identification of persons or items in the Republic of Serbia and Federal Republic of Germany. There are several reasons for choosing these two states for comparative analysis. Both states belong to the European continental legal system, which implies that they have the similar legal tradition. The Federal Republic of Germany is one of the leading states of the European Union and the Republic of Serbia is in process of the accession to the EU, which requires adjusting the legal framework to the rules of the EU, including the rules that are related to judiciary and the police. Also, both states have the prosecutorial investigation model, but Germany has been following this model of investigation much longer, and therefore has considerable practice related to this issue.

In both states, police have the authority to conduct this action in pre-investigation and investigation phase and the results can be presented in the criminal proceedings. The legal provisions that regulate the eyewitness procedures can be found in the Criminal Procedure Code, but there are differences regarding the question of 
who may approve this action and the legal framework regulating the manner in which it is carried out. One of the similarities is related to the fact that police may conduct direct identification of persons or items or identification based on the photographs, but there are differences related to the rules on forming the identification lineup and photo array. This issue is important, because there are opinions that the manner of forming the lineup or photo array may affect the objectivity of the witness in the process of identification. The manner of conducting this action may also be significant in later criminal proceedings, in which court will assess the probative value of the identification.

\section{The legal procedures in eyewitness identification in the Republic of Serbia}

In the Republic of Serbia, eyewitness identification is regulated by the provisions of the Criminal Procedure Code and consists of showing the person or item to the witness. Identification of the persons or items will be conducted if it is necessary to determine whether an eyewitness recognizes a particular person or item, or their characteristics, which he or she described (The Criminal Procedure Code, 2011, art. 100). This provision provides that an identification procedure will be conducted according to the article 90 of the Code, which stipulates that the person or item will be shown to the eyewitness, along with other unknown persons or items whose basic characteristics are similar to those previously described by eyewitness. After that, eyewitness will be asked to give a statement as to whether he/she can identify the person or item and to clarify whether identification is conducted with certainty or with a certain degree of probability.

Also, legal provisions recognize the situation in which police have an eyewitness in the case, but the suspect or item related to crime are not available, so there is a possibility of showing the witness a photograph of that person or item. A photograph of the suspect or item will be shown along with photographs of unknown persons or items whose basic characteristics are similar to those described by the eyewitness. Beside direct identification and identification by photographs, according to provisions of the Criminal Procedure Code, 
identification of the person can be conducted on the basis of his or her voice (art. 90, para. 4).

In the pre-investigation and investigation phase, protection of the witness must be ensured, so that the person who is subject of identification cannot see the witness during the process of identification. Also, in order to ensure the objectivity of this action, police must guarantee that the witness will not see the person who is the subject of identification before the formal identification procedure begins. In this phase, the presence of public prosecutor is required. Legal provisions do not imply that presence of a suspect's attorney is needed, but his presence is desirable in order to prevent subsequent remarks on the official record, later in the criminal proceedings (Tasić, Lajić, 2019:175). It is important to emphasize that in case where the person who is a subject of identification is treated as a suspect, he or she must be notified about all legal rights belonging to him or her as a suspect, including the right to an attorney who can be present during the identification process. If the suspect was not informed of the right to attorney, so he or she was not able to state about his presence during the identification procedure, that could be interpreted as a violation of procedural provisions (Supreme Court of Cassation of the Republic of Serbia, Kzz. 1326/17). Also, the essential provisions of the criminal procedure will be violated in case of presence of one or more attorneys who represent - at the same time - an eywitness and a suspect, because these parties have oposite interests (Supreme Court of Cassation of the Republic of Serbia, Kzz. 622/18).

\section{The legal procedures in eyewitness identification in the Federal Republic of Germany}

The Criminal Procedure Code in the Federal Republic of Germany - Strafprozessrech (StPO) incorporates all basic procedural principles relevant for the criminal proceedings (Saive, 2014). The identification procedure, which is part of the witnesses' testimony and thus falls criminologically under the subjective production of evidence, is legally divided into two areas - normative requirements concerning witnesses and the accused.

The witness identification procedure is regulated in chapter VI of the StPO, in the section that refers to the examination and 
confrontation of the witnesses (StPO, §58). This provision indicates that witnesses shall be interrogated individually and in the absence of the witnesses who are going to be heard subsequently. Further, a confrontation with other witnesses or with the accused in the preliminary proceedings shall be admissible, if this appears necessary for the further proceedings. Both intervention measures can be dispositioned and implemented by police officers. In case of a personal confrontation, the lawyer of the accused has the right to be present; if he has no time on the date the police officers set, it is his fault. So with this regulation the police are allowed to interrogate witnesses, show them pictures of past offenders in order to find a suspect, of the suspect hidden among the pictures of comparables in hope that he or she may identify a known suspect or show them the suspect among the comparables.

The defendant's duty to cooperate in identification proceedings is regulated in chapter VII of StPO, which refers to the experts and inspection, in section 81a - physical examination of the accused; admissibility of physical interventions. Forced changes to the external appearance of the defendant may be made. These are changes such as, for example, the hair or beard costume as well as his clothing. These measures may be ordered by the police officers, as in the case of witnesses. A special authorization is required only in the case of a compulsory use of this measure. If the accused is at large and is not in custody, the authority to order a summons to stand trial lies with the public prosecutor's office pursuant to section 161a para. 1, 163a para. 3 StPO (Schmitt, Meyer-Gossner, 2019:81a; Steinert, Ulf, 2008).

Also, section $81 \mathrm{~b}$ StPO, which regulates the identification measures at the defendant's premises, contains two relevant legal bases for the identification treatment of an accused person. A distinction is made between the first and second alternatives. In the first alternative, physical features may be described and measured in addition to photographs of the accused. In this respect, portraits, full body photographs and, if necessary, special photographs are taken of the accused from different perspectives, fingerprints are taken and a descriptive documentation of his personal appearance is produced. These documents, unless they are also subject to the second alternative, must be destroyed at the end of the criminal proceedings. The second alternative is a preventive measure to prevent future crimes 
on the one hand, but also to improve their investigation on the other. If the police officer in charge affirms in a criminal prognosis that the accused is at a risk of repeating crime, the data collected under alternative one can be stored in the police file systems. This means that with a corresponding prognosis and proof of a confirmed crime, these data can be stored in police data systems and used to create both photo showcases and election photo templates with digital support (Schmitt, MeyerGossner, 2019:81b; Kramer op. 2009, S. 190ff.).

\section{Supplementary directives in criminal proceedings and binding court rulings}

Considering Gestalt psychology, which distinguishes between the categories of the principle of totality and principle of psychophysical isomorphism in the design of the perceptual experience of persons and thereby influences the perception by reification, multistability and invariance of the Gestallt laws drawn up by Wertheimer (Wertheimer, 1923), the presentation of a choice picture template or, alternatively, a confrontation is usually feasible only once (Ackermann et al., 2019:383). In particular, the law of similarity and proximity prove the strong influence of an already carried out election photo submission or election confrontation and a repeated or stronger focus on the first round than on the original act is obvious and therefore not legitimate by the procedural principles. This scientific knowledge was implemented in the Guidelines for Criminal Proceedings and Fines Proceedings of Germany (RiStBV) as court rule $\mathrm{Nr} 18 \mathrm{Abs}$ 3. If it is to be clarified by a comparison whether the accused is the perpetrator, not only the accused but also a number of other persons of the same sex, similar age and similar appearance shall be confronted with the witness in a form which does not reveal who among the persons confronted is the accused. The comparison shall in principle be made one after the other and not simultaneously, with the provision that at least eight persons shall be shown to the witness. It shall also be carried out in full if the witness declares in the meantime that he has recognized a person. The details shall be recorded. 


\section{Criminalistics rules in direct eyewitness identification procedure in the Republic of Serbia}

The Criminal Procedure Code provides basic procedural framework for undertaking identification procedure, so there is a need to consult criminalistic theory and practice in order to answer specific questions related to this procedure. In order to conduct direct identification procedure, police must have a suspect for the crime and a victim or an eyewitness who are able to identify that person as a suspect. At the beginning, criminal investigators will ask the eyewitness to describe in detail the persons whom he/she noticed as an offender or an item relevant to the crime. A detailed description means that the witness must describe some individual, specific characteristics which could clearly distinguish that person or item from other, similar persons or items.

Forming an identification lineup is one of the important issues, so there is a question if the administrator of identification will form the line based on the description given by the witness or based on the physical appearance of a potential suspect (Clark et al., 2015:180). Because the witness's description of the offender may vary in its accuracy, in practice, persons for lineup will be more frequently selected because of their similarity to the suspect. This approach neglects the fact that the suspect may or may not be the offender. Also, the manner of finding persons for the purpose of forming the identification lineup can be disputable, because of the fact that police often use their colleagues with appropriate physical appearance, sometimes even those who are working on the case. That can be a problem because the witness may have had a contact with these persons and may know that they are police officers. It is clear that in some cases police cannot achieve total similarity between the suspect and other persons in the identification lineup, but it is desirable that persons in the lineup are similar in terms of sex, age, height, race, color of eye and hair, haircut and general body constitution. Forming the lineup with persons who fit the description of the offender is important, because confidence of the eyewitness can grow if there is only one person who fits the description, so that it can lead to the false identification of an innocent person (Wells et al., 1998:616). 
Police should respect legal and criminalistics rules during the implementation of this action. One of the most important legal rules is that the eyewitness should not see the offender before the identification procedure starts. Criminal investigators should not present photographs of the suspect to the eyewitness or give any information about his appearance and this issue is often a reason for disputing the official record of identification later in criminal proceedings. In some cases, courts have expressed the opinion that if a criminal investigator had showed multiple photographs of different persons to eyewitness, not exclusively photographs of the suspect, this could be interpreted as operative action undertaken to identify the offender of the crime which does not affect legality of the identification action that was subsequently taken (Supreme Court of Cassation of Republic of Serbia, Kzz. 1087/18).

In Serbia, eyewitness memory is usually tested by simultaneously presenting one suspect together with four similar persons, so the lineup is formed of 5 persons. Each space in line is marked with numbers from 1 to 5 , so the eyewitness can make two decisions: to choose an individual from the lineup, indicating the number under which they are located or to reject the lineup because he cannot identify the offender (Gronlund et al., 2014:4). This number is adequate because allows the witness to have all the persons in his field of vision, so he can focus and perform this action with full attention. This model of performing the identification is criticized because it encourages a relative assessment of identity, as opposed to the sequential identification in which eyewitness makes a decision about each person presented, before being presented with the next one (Fazlić, 2016:61). Administrator will give the instruction to the witness that in lineup may or may not include the person previously described as an offender, so that he or she should look carefully at each person. In case of recognizing a certain person as an offender, the eyewitness will indicate the number under which the offender is marked, and then the identified person will step forward from line. The last step means that the eyewitness must state whether the identification is conducted with certainty or with a certain degree of probability. As a result of the implemented identification procedure, police must make an official record. 


\section{Identification of persons based on photographs}

According to legal provisions, if a person or item is not available, photographs of that person or item can be used for the purpose of identification (The Criminal Procedure Code, 2011, art. 90). This provision emphasizes that such identification will be conducted in exceptional cases where direct identification cannot be conducted.

Usually, this kind of identification is used in cases where police know the identity of the offender, but the offender has not yet been arrested or brought into the police premises. For many years, police used photo albums of offenders which were manually created and classified by type of criminal offence. These albums had a great operative significance in early investigation, because they were presented to the eyewitnesses in order to identify the perpetrator of the crime (Žarković, 2017:94). One of the main reasons for abandoning manual preparation of photo albums is that now the police can use a unique information system which contains signaletic photographs of persons who are forensically registered. For the purpose of identification, photographs of the persons will be extracted from the unique information system, based on the description given by the witness. Criminal investigators will show 5 photographs, including the photograph of the potential suspect, so the witness will see all photographs at the same time, marked with numbers. As in the case of direct identification, all legal and criminalistics rules are the same.

\section{Criminalistics rules in direct eyewitness identification procedure in the Federal Republic of Germany}

There are two criminalistics procedures that can be applied and the main characteristic which distinguishes them is the way they are conducted. The first one implies that the identification can be concealed and other that identification can be openly carried out. Depending on the tactical assessment, both for the tactically clever approach and for the protection of the witness, the comparisons can be carried out undercover, i.e. without noticing the suspects or by confrontation. In the case of confrontation, there are differences between simultaneous and sequential confrontation. The simultaneous 
confrontation usually takes place under cover in the course of search measures, in which the witness is supposed to recognize the accused from an arbitrary selection of passers-by. Usually, this is a group of suspects who have been found near the crime scene and there is no specific suspicion yet. The aim is for the witness to name the suspect from a natural environment without the police being able to name a suspect or defendant beforehand.

In contrast, the sequential comparison serves to confirm the suspicion of police investigations and therefore does not take place in the acute phase of the investigation of the security attack but in the course of further investigations, i.e. the evaluation attack. In this respect, appropriate preparation is required, which must take into account the compared persons in particular. These must be similar to the suspect. This is a practical problem, because you need at least 7 persons whose looks are similar to those of the suspect. In accordance with the judgment of the Federal Court of Justice of 9 November 2011, in which electoral photographs must be presented sequentially, to the end and with at least 8 suspects, these principles should also be observed in a personal confrontation, regardless of whether it takes place confrontatively or the witness is concealed behind a Venetian mirror (Kramer op. 2009, 191 ff; Ackermann et al., 2019, S. 335ff.). Due to the uniqueness and non-reproducibility of the identification procedure of any kind, the documentation plays an important and decisive role in its implementation, as this later forms the basis for proof in court.

\section{Identification process by means of a voting photo original}

There are two different procedures for the presentation of selected photographs of possible suspects. On the one hand, when identification involves showing a photograph, the shows card index in which suspects from other criminal proceedings are stored is presented to the witnesses in the hope that they can recognize and name a suspect. It is important that the photographs shown are stored according to the second alternative (preventive purposes) according to $\S 81 \mathrm{~b}$ StPO. On the other hand, there is the sequential election photo template, which is used if there is already a suspect. Then, as in the above-mentioned court ruling, at least 8 persons for comparison must be selected, these must be presented to the witness sequentially to the 
end and his statements must be recorded. For better usability, the suspect should be neither in the first nor in the last position. If all comparison pictures are uniform and only the search photo is, for example, from a surveillance camera, the outcome of this photo-lineup will, if anything, be inconclusive (Ackermann et al., 2019, S. 399).

\section{Discussion}

Bearing in mind legal and criminalistics procedures related to eyewitness identification in Serbia and Germany, the issue to be discussed concerns the advantages and disadvantages of these procedures.

One of the most important issues concerning eyewitness identification is related to the probative value of this action in the criminal proceedings. According to law provisions in Serbia, identification of persons or items is not a separate proving action, but it is an action for verifying the credibility of the evidence that has already been obtained (Grubač, 2008:230). This implies that the eyewitness who performed the identification in police premises in preinvestigation and investigation phase will be interrogated later in criminal proceedings, so the identification of the offender will be an integral part of the witness's testimony in court. The main reason for this is the rule that a court judgment can only be based on evidence presented at the main trial. Also, the official record made by police is evaluated as part of the assessment of the credibility of the witness's entire testimony and other evidence presented in court (Supreme Court of Cassation of Republic of Serbia, Kzz. 33/15). On the other hand, the identification procedure in Germany, regardless of the form in which it has been used by the police (election confrontation, election photo submission or with a photo submission file), is regarded as evidence in court. The results of this identification will be presented orally both by the eyewitness and by investigating police officers later in criminal proceedings. It is important that this action is properly documented by the police officer. The probative value of such an identification procedure in court depends of the subjective evaluation of a judge and how high he regards the respective concrete measure for identification as evidence relevant. However, if there are no procedural errors, they must at least be taken into account as evidence in the judgment. 
In Serbia, police can conduct this proving action in the preinvestigation or investigation phase with consent of public prosecutor, who must be present during identification procedure, so it could have probative value. In Germany, this action can be ordered independently by the police officers, who are also investigators of the public prosecutor's office. Only the forced presentation of an accused person to carry out the measure requires an order from the public prosecutor's office. Also, the presence of the public prosecutor during the identification procedure is not required. In both states, an offender has the right to call his attorney who can be present during the identification procedure, but it is not necessary condition. This implies that potential absence of the attorney will not have any impact on the probative value of this action.

There are differences related to the number of persons or photographs that should be used for eyewitness identification procedure. In Serbia, the identification lineup will be formed of five persons, including the accused, while in Germany the lineup will be formed of eight persons. This rule also applies for the case of photo array, but in Serbia photographs and comparables will be manually selected and compiled by the investigating police officers, while in Germany it is possible to extract these from the existing police systems.

\section{Conclusion}

A comparative analysis indicates that, essentially, there are similarities in the implementation of the identification procedures in both states. However, there are five main differences, which are based on normative procedural rules. From a criminalistic point of view, these differences are insignificant.

In both states, eyewitness identification is accepted as a proving action and its results can be used as evidence in court. In Germany, this action can be ordered independently by the police officers, while in Serbia the public prosecutor must be consulted, because his presence is required. It can be concluded that German police have broader powers and more independence in respect of the eyewitness procedure, because police officers are also investigators of the public prosecutor's office, so the presence of the public prosecutor is not needed in order for this action to be proof at court. In both states, 
the results of this action will be evaluated in court, but in Germany, both the eyewitness and the police officer will orally report about the identification procedure later before the court. In Serbia, only eyewitness will be asked again by the judge to confirm identification of the accused. Also, both states respect the right of the offender to call the attorney who can attend the identification procedure. In the case where attorney does not appear on the date determined by the police, the identification procedure will be carried out without the attorney and this will not affect the probative value of this action.

One of the advantages in the German eyewitness procedure is related to the identification lineup and photo array, because the lineup consists of eight persons, including the suspect and they are presented to the eyewitness sequentially. In Serbia, only five persons, including the suspect, form the lineup, so there are fewer possibilities for the eyewitness to choose the suspect among the persons in lineup. Also, the suspect will be shown simultaneously with the other persons in the lineup. On the other hand, police in Germany will have more difficulties to find the required number of persons who are similar to the suspect. It could be concluded that the identification procedure in Serbia should be changed in accordance with the German criminalistic practice, so that the lineup should include a larger number of persons in order to increase the objectivity of the identification. Regarding the photo array, German police are better supported by existing police data systems, while in Serbia both photographs and fillers have to be manually selected and compiled by the investigating police officers. This implies a need for improving the existing police data systems in Serbia.

This comparative study showed that Germany and Serbia have similar rules for conducting the eyewitness identification procedure, but in Serbia this procedure is more precisely described in the Criminal Procedure Code. This implies that more differences can be found in procedural provisions, than in criminalistic practice. Regardless of this, there is a need to share practical experiences within the field of crime investigation science in order to improve existing criminalistic practice and legal provisions. 


\section{References}

1. Ackermann, R., Clages, H., Roll, H. (2019). Handbuch der Kriminalistik. Kriminaltaktik für Praxis und Ausbildung. Stuttgart: Boorberg Verlag.

2. Bošković, M. (1999). Kriminološki leksikon. Novi Sad: Matica Srpska.

3. Clark, S. E., Benjamin, A. S., Wixted, J. T., Mickes, L., Gronlund, S. D. (2015). Eyewitness Identifiication and the Accuracy of the Criminal Justice System. Policy Insights from the Behavioral and Brain Sciences, 2 (1), 175-186.

4. Fazlić, A. (2016). Simultano ili sekvencijalno prepoznavanje? Postoji li ispravan odgovor? Kriminalističke teme, Časopis za kriminalistiku, kriminologiju i sigurnosne studije, 16 (3-4), 57-73.

5. Grubač, M. (2008). Krivično procesno pravo. Beograd: Pravni fakultet Univerziteta Union: Službeni glasnik.

6. Jokić, D. (2016). Prepoznavanje lica i predmeta. Banja Luka: Internacionalna asocijacija kriminalista Banja Luka.

7. Kramer, B. (op. 2009). Grundbegriffe des Strafverfahrensrechts. E rmittlung und Verfahren. Stuttgart: Kohlhammer.

8. Supreme Court of Cassation of Republic of Serbia (2018). Case Kzz. 1087/18.

9. Supreme Court of Cassation of Republic of Serbia (2017). Case Kzz. 1326/17.

10. Supreme Court of Cassation of Republic of Serbia (2018). Case Kzz. 622/18.

11. Supreme Court of Cassation of Republic of Serbia (2015). Case Kzz. 33/15.

12. Saive, D. (2014). Prozessmaximen und -prinzipien der StPO. In Juraexamen.info 2014

13. Schmitt,B.\&Meyer-Gossner,L.(2019). Strafprozessordnung. Gerichtsverfassungsgesetz, Nebengesetze und ergänzende Bestimmungen. München: C. H. Beck

14. Steinert Ulf (2008). Erkennungsdienst, erkennungsdienstliche Behandlung,

15. Wiedererkennungsmaßnahmen. Brandenburg.

16. Tasić, M., Lajić, O. (2019). Characteristics in investigating and proving robberies. In: $10^{\text {th }}$ International Scientific Conference, The 
great powers influence on the security of small states, Vol. II, 170178, Skopje.

17. The Criminal Procedure Code, Official Gazette of the Republic of Serbia, number 72/2011, 101/2011, 121/2012, 32/2013, 45/2013, $55 / 2014$ and $35 / 2019$.

18. Wells, G. L., Small, M., Penrod, S., Malpass, R. S., Fulero, S. M., Brimacombe, C. A. E. (1998). Eyewitness Identification Procedures: Recommendations for Lineups and Photospreads. Law and Human Behavior, 22 (6), 603-647.

19. Wertheimer, M. (1923). Untersuchung zur Lehre von der Gestalt. In K. Koffka, W. Köhler, M. Wertheimer, K. Goldstein \& H. Gruhle (Hrsg.), Psychologische Forschung. Zeitschrift für Psychologie und deren Grenzwissenschaften. Festschrift für Carl Stumpf. S. 301-350. Berlin: Verlag von Julius Springer.

\section{Aktuelne pravne i kriminalističke mogućnosti u sprovođenju postupka prepoznavanja od strane svedoka - komparativna analiza standarda u Nemačkoj i Srbiji ${ }^{2}$}

Apstrakt: Predmet rada je komparativna naučna analiza mogućnosti u sprovođenju postupka prepoznavanja od strane svedoka $u$ Saveznoj Republici Nemačkoj i Republici Srbiji, zbog činjenice da prepoznavanje predstavlja jednu od dokaznih radnji u obe države. U radu će biti razmotrene prednosti $i$ nedostaci postupka prepoznavanja $u$ ovim državama, u cilju utvrđivanja optimalnog postupka koji bi podjednako bio efektivan i objektivan za svedoke i za osumnjičenog.

Iako postoje sličnosti u sprovođenju postupka prepoznavanja, javljaju se i pojedine razlike koje suštinski proističu iz normativnih pravila kojima se utvrđuje da li policija ima izvorno ovlašćenje da sprovede ovu radnju ili je potrebna autorizacija od strane tužioca. Takođe, razlike su primetne $i$ u pogledu načina formiranja linije za prepoznavanje i foto albuma, naročito u pogledu broja lica ili fotografija koje će biti predočene svedoku, zajedno sa osumnjičenim.

\footnotetext{
${ }^{2}$ Rad je nastao u okviru projekta Ministarstva prosvete, nauke i tehnološkog razvoja Republike Srbije, pod brojem 179045.
} 
Naučna opravdanost rada ogleda se u činjenici da je neophodno postojanje jasnih standarda u sprovođenju radnje prepoznavanja, te postoji i potreba za uspostavljanjem adekvatnih preduslova kako bi se ova radnja mogla koristiti u krivičnom postupku, naročito u slučajevima koje odlikuje nedostatatak materijalnih dokaza.

Ključne reči: prepoznavanje, svedoci, procesne odredbe, kriminalističke metode. 